\title{
New business formation in a rapidly growing economy: the Irish experience
}

\author{
Michael Anyadike-Danes \\ Economic Research Institute of Northern Ireland \\ Mark Hart \\ Aston Business School, Aston University \\ Helena Lenihan \\ Department of Economics, Kemmy Business School, University of Limerick
}

May 242009

\begin{abstract}
The extraordinary growth of the Irish economy since the mid-1990s - the 'Celtic Tiger' - has attracted a great deal of interest, commentary and research. Indeed, many countries look to Ireland as an economic development role model, and it has been suggested that Ireland might provide key lessons for other EU members as they seek to achieve the objectives set out in the Lisbon Agenda. Much of the discussion of Ireland's growth has focused on its possible triggers: the long term consequences of the late 1980s fiscal stabilisation; EU structural funds; education; wage moderation; and devaluation of the Irish punt. The industrial policy perspective has highlighted the importance of inflows of foreign direct investment, but a notable absence from the discourse on the 'Celtic Tiger' has been any mention of the role of new business venture creation and entrepreneurship. In this paper we use unpublished Irish VAT data for the years 1988 to 2004 to provide the first detailed look at national trends in business birth and death rates in Ireland over the 'take-off' period. We also use subnational VAT data to shed light on spatial trends in new venture creation. Our overall
\end{abstract}

\footnotetext{
* Thanks to the Irish Revenue Commissioners for access to the unpublished VAT data as well as comments from audiences at conferences and seminars in Limerick (EUNIP), Paris (ERSA) and the Centre for Business Research at Judge Business School (University of Cambridge) where Helena Lenihan was on sabbatical for part of 2008. The usual disclaimer applies.
} 
conclusions are that new business formation made no detectable contribution to the acceleration of Ireland's growth in the late 1990s, although we do find evidence of spatial convergence in per capita business stocks.

\section{Introduction: Ireland's Economic Transformation}

The transformation of Ireland's economic fortunes since the mid-1990s has attracted a great deal of academic and policy interest as other small economies seek to learn the lessons from this late 20th century growth 'miracle' commonly referred to as the 'Celtic Tiger'. Irish GNP per head in 1987 stood at 59 per cent of the EU15 average, largely unchanged from its 1960 position, but by 1997 it had risen to 88 per cent (Barry [1999, p. 1]). This growth showed up in the labour market as numbers at work increased at an annual average rate of 2.1 per cent over the same period, and the unemployment rate fell from 17.1 to 10.3 per cent (Barry [1999]; Harris [2005]). That growth continued beyond 1997 and in the period 1996-2002 Ireland recorded annual growth rates in GNP of 6.9 per cent with annual employment growth rates of 4.3 per cent (Cassidy [2004]). Irish GNP per head is now roughly equal to the EU average and about 70 per cent of the US (Cassidy [2004]).

The obvious question is: what factors were responsible for this transformation? Many have been proposed but, perhaps surprisingly, there is quite widespread agreement as to the factors that played a role, although, as Barry has suggested: "... the emphasis placed on the various components will differ as always with the storyteller" Barry [1999, p.1] Much of the discussion has focussed on potential "triggers": the long-term consequences of the late 1980s fiscal stabilisation; EU Structural Funds; wage moderation; education; the promotion of competition and improvement in telecommunications; currency devaluation; and a booming US economy.

From an industrial policy perspective, the focus has been primarily on the importance of foreign direct investment (FDI) inflows and to a lesser extent on the performance of an indigenous stock of firms (i.e., through the processes of business start-up, survival and growth). What has been largely missing from the industrial policy discourse is an explicit consideration of the role of new business venture creation and entrepreneurship in the rapid growth of the Irish 
economy. This, we argue, is somewhat surprising given the debate in academic and policy circles about the relationship between entrepreneurship and economic development. For example, a number of studies have identified entrepreneurship as an important driver for economic growth, competitiveness and job creation (Thurik and Wennekers [2004]; Wennekers et al. [1999]; van Stel et al. [2005]).

Nevertheless, we still face the obvious, but nonetheless fundamental, question: are big business birth rates, where they occur, a cause of economic progress in those places or an effect, or a by-product of the factors driving the growth process? It has been argued that the continual entry and exit of firms and plants is vital to economic success. Often described as 'churn', this process is seen as having a positive effect on productivity through increased competition leading to cost efficiency. Further, it may enhance a process of creative destruction as more innovative firms enter the market place and displace existing businesses using old, or at best, current technologies. ${ }^{1}$ Contributing to this debate a number of authors have looked at the role of new business creation in developing regional growth 'systems' (see for example, Plummer and Acs [2005]; Fritsch and Mueller [2004]; van Stel and Storey [2004]). For these authors, regions matter when studying the relationship between new firm formation and job creation or, more generally, economic growth. It is only at this scale of analysis, they argue, that the variations in new firm formation can be clearly understood.

What we are presented with in the case of Ireland is a unique opportunity to investigate the relationship between new business formation (i.e., births) and rapid economic growth. With the newly available the Irish VAT data on registrations (entry) and deregistrations (exit) for the period 1988 to 2004 we can now investigate the nature of the relationship between business entry and economic growth during the exceptional period since the mid-1990s. Whilst VAT datasets have obvious shortcomings when studying new business formation, (see the discussions of the data in Ashcroft et al. [1991]; Johnson and Conway [1997] and Anyadike-Danes et al. [2005]), they are widely used, and in our case we are able to examine the extent to which business birth and death rates are connected to the rapid growth and expansion of the Irish economy in the 1994-1999 period. 
The paper is structured as follows. Section 2 reviews the existing literature on new business formation and economic growth, followed by a brief exposition of the principal arguments advanced to account for the unprecedented growth in the Irish economy since the mid-1990s. Section 4 describes the trends observed in the VAT 'births' and 'deaths' in Ireland at both national and sub-regional level for the period 1988-2004 and seeks to investigate the extent to which these trends can be connected to rapid economic growth since 1994. This includes a discussion of the relationship between business birth rates and employment rates at the national level. The paper concludes with some comments on what the wider international research agenda linking new business formation, entrepreneurship and economic growth might learn from the Irish experience.

\section{New Business Formation and Economic Growth in Ireland - a missing discourse?}

As outlined by Wennekers and Thurik [1999, p. 30] "Empirical research on the role of entrepreneurship as a driving force of economic development still is not well developed". Audretsch and Thurik [2001] also argue that there has been a general absence of studies linking the impact of entrepreneurship on macroeconomic performance at country level. However, one recent study by Bartelsmann et al. [2004], which examined harmonised data on entry and exit rates for 24 industrial and developing countries (though not for Ireland) found evidence of a high correlation between entry and exit rates and that this process of creative destruction was a positive driver of productivity growth.

In the case of Ireland, there has been an almost complete absence of any discourse regarding the relationship between new business formation and the growth of the Irish economy. In other words, there has been no investigation of the extent to which rates of new business formation were a significant driver. Barry [1999] comments (expressing a commonly held view) that the record levels of job creation were largely concentrated in market services. However, he also points out that manufacturing-sector employment has also risen, in both indigenous and foreign-owned sectors. Further, Burnham [2003] observes that the construction sector and financial and other business services sectors have 
also showed significant increases. However, surprisingly, the discussion has never recognised that one of the drivers of Irish economic growth may have been entrepreneurship. In other words, nowhere have commentators sought to investigate the extent to which entrepreneurship - as manifest for example in new business venture activity - may be connected to exceptional economic growth.

There has been a body of work using firm and plant-level demographic data in Ireland following an established international methodology for investigating the processes of job creation and destruction as well as entry, exit and survival rates (see, for example, Strobl et al. [1998]; Gorg and Strobl [2002], Gorg and Strobl [2003]. These studies have focused solely on the manufacturing sector and relate to time periods immediately prior to Ireland's economic 'take-off'. As a result they cannot directly inform the specific research question of this paper. Nevertheless, they have made an important contribution to our understanding of the processes underlying the changes in the business stock over time and we will return to their findings later as we seek to interpret the results of our analysis of births and deaths for the 1988-2004 period.

One of the few papers that has addressed the relationship between economic growth and new venture creation and entrepreneurship in Ireland is that of Acs et al. [2007b] which examines the question of whether the Irish miracle could be repeated in Hungary. ${ }^{2}$ This paper builds on internationalization theory and uses data from the Global Entrepreneurship Monitor (GEM), to explore whether, and if so how, the policy of attracting inward FDI from multinational enterprises impacts on indigenous entrepreneurial activity. The authors argue that the period of rapid growth in the 1990s was characterised by an increase in the number of new businesses. They point out that this entrepreneurial activity was concentrated in sectors related to the increase in domestic demand. More specifically that: "... the rapid increase in the size of the Irish labour force translated into an increase in consumer spending, in real terms, of about 75 per cent between 1993 and 2003" Acs et al. [2007b, p. 131]. However, a major weakness of this analysis, which we address in this paper, is that the GEM data is only available from 1999 onwards so they are unable to look at the degree of entrepreneurial activity in the period prior to rapid economic growth in Ireland (i.e., from 1994 onwards). 
Using VAT registration data $^{3}$, Acs et al. [2007b] report that in 2000 entrepreneurial activity was most concentrated in the construction sector (33\% of new VAT registrations) and other professionals, with the latter group being made up of architects, advertising, barristers, solicitors and legal agents (20\% of net new VAT registrations). They also suggest that policies adopted by the development agencies were key to facilitating entrepreneurial activity in the software sector. A number of authors (e.g. Burnham [2003]) also refer to the emergence of several Irish-owned and Irish-managed start-ups in the software and internet sectors beginning in the mid 1990s.

\section{Factors that have contributed to the phenomenal growth of the Irish economy}

What have been the key contributory factors which have brought about the phenomenal growth of the Irish economy since 1994? Many countries are now looking to Ireland as an economic development role model and the list of stylised explanatory factors has travelled widely. The Sapir Report (Sapir et al. [2003]) has, for example, highlighted the fact that Ireland should be seen as providing key lessons for other countries of the EU in realising the Lisbon Agenda. The key factors commonly suggested as having contributed to the 'Celtic Tiger' include: in-flows of FDI; investment in infrastructure and other projects through the EU Structural Funds (Barry [1999]; Burnham [2003]; Andreosso-O'Callaghan and Lenihan [2006]); wage cost stability through national agreements with the social partners McAleese [2000]; fiscal stabilisation McAleese [2000]; administrative capacity and a supportive macroeconomic environment Bailey et al. [2007]; improved education levels and increasing participation rates Harris [2005].

However, there is a rather more unexciting interpretation of Irish economic growth. Some commentators prefer to describe it as a simple story of 'catch-up' by a 'lucky' (and small, around 1 per cent of the US or EU economy) regional economy (Barry [2002]; Honohan and Walsh [2002]). The economy was extremely open to trade and factor flows and had a currency pegged to an external unit. Viewed like this Irish growth was unexceptional in US terms 
(e.g., 23 out of 50 states grew faster in the same period) although it was unmatched in the EU. In short, it is perhaps better thought of as a 'deferred and telescoped process'.

A closer examination of the role of FDI offers an opportunity to examine the ways in which it might impact upon new firm formation rates in Ireland. It is widely accepted that FDI, and to a large extent US FDI, has been a key trigger of economic growth and development in Ireland. As outlined by Gray: " ... it is not an exaggeration to say that the growth in foreign investment is at the heart of an understanding of the Irish economic miracle." Gray [1997, p. xviii]. Acs et al. [2007b] concur when they state that the Irish economic 'miracle' was brought about in: "... large part by attracting technology through Foreign Direct Investment." Acs et al. [2007b, p.123]. The evidence is clear, using data from UNCTAD's 1999 World Investment Report, Ferreira and Vanhoudt [2004] write: "... the FDI inward capital stock has increased from approximately UDS 3.7 billion in 1980 to 23.9 in 1998 . Hence, Ireland ranks number 1 in terms of growth in its foreign-owned capital stock with a solid performance of 20 per cent a year on average over the 1990-98 period." Ferreira and Vanhoudt [2004, p. 225]. The significance of FDI is further quantified by Harris [2005] when he argues that between 1990 and 2002 the number of companies exporting from Ireland rose from 11,000 to 70,000 .

Starting with the 'First Programme for Economic Expansion' Department of Finance [1958], Ireland's industrial strategy approach has focussed on the attraction of MNEs. In particular, as outlined by Buckley et al. [2006], when Ireland joined the European Economic Community in 1973, the Industrial Development Authority pursued a selective and targeted approach to attract investment from abroad in electronics, chemicals and other 'high technology' industries. Such industries, as outlined by Braunerhjelm et al.[2000], are ideal for peripheral locations such as Ireland, since they produce high-value goods which do not entail high transportation costs. Slaughter [2003] and Barry [2004] argue that Ireland's geographic proximity and strong cultural links between Ireland and the US have been important factors in attracting US FDI, reinforced by Ireland's membership of the EU which allowed US businesses to use Ireland as a base for serving the European Market (Foley and McAleese [1991]). 
This pre-occupation with the role of FDI may explain why entrepreneurship does not feature in mainstream discussion of the factors leading to Ireland's economic growth. There are two important exceptions. First, the recent work by Gorg and Strobl [2002] on plant-level data for the manufacturing sector which revealed that there was a positive effect of the presence of foreign MultiNational Corporations (MNCs) on the entry of indigenous firms into the sector in the decade from the mid-1980s. This positive effect operates through the presence of MNCs in the same manufacturing industry as well as the presence of MNCs in downstream manufacturing activity. A later paper by the same authors (Gorg and Strobl [2003]) found that the survival rate of indigenous manufacturing plants was also enhanced by the presence of MNCs. However, there has been no attempt made in the research to assess the extent to which new venture creation was a major driver of Ireland's growth since the mid1990s. More recently, Acs et al. [2007a], again using GEM data for Ireland and Wales since 1999, argue that there is support for a knowledge spillover theory of entrepreneurship connected to FDI projects in Ireland. Both these studies suffer from the disadvantage that they do not span a time period that allows a comparison of pre- and post-growth periods in Ireland.

\section{$4 \quad$ New Business Formation in Ireland 1988-2004}

\subsection{Data}

This paper uses almost twenty years (1988 to 2004) of previously unpublished VAT data. This dataset was provided by the Revenue Commissioners and was classified by bailiwick (broadly Irish counties). ${ }^{4}$ From the outset it should be acknowledged that it is not being assumed that the VAT data provides the only, or best, measure of vital rates in the business sector. But it is one that policymakers have typically used across the EU, and indeed are likely to continue to use, given present alternatives. So, for the purposes of the paper, all reservations about the limitations of VAT statistics as a proxy and/or their deeper meaning should be taken as understood. ${ }^{5}$ Most particularly, there is no presumption that these statistics have anything to say about some latent 
construct such as the "entrepreneurial spirit" or propensity towards business ownership of a region or county in Ireland.

In the analysis that follows we use only the aggregated annual data on business 'births' and 'deaths' as proxied by registrations, re-registrations and cancellations. ${ }^{6}$ We adopt an ecological approach to the standardisation process and express vital rates (i.e., births and deaths) as a ratio to the stock of businesses. This is identical to the approach adopted in a recent analysis of the UK VAT data (Anyadike-Danes et al. [2005], Anyadike-Danes and Hart [2006]). For example, we measure the birth rate as the number of new firms 'born' during a period divided by the stock of firms at the beginning of the period. This contrasts with those authors (e.g. Ashcroft et al. [1991]) who adopt a labour market approach and standardise the birth and death data using population or employment numbers in order to reflect the view that the owners of business start-ups are likely to be drawn from participants in the local labour market.

Opinions differ about the merits of both these approaches (see, for example, Love [1995]) but we argue that the ecological approach is more relevant in this analysis of the Irish VAT data as we are seeking to understand the dynamics of the business stock over a period of rapid economic growth. Our principal concern is to provide a simple and relatively transparent framework for investigating the contributions of the 'gross birth rate' and 'gross death rate' to the 'net birth rate' and thus the size of the stock of businesses over time and across sub-national administrative areas (i.e. bailiwicks) in Ireland. Both birth and death rates need to be measured on a comparable basis and the ecological approach has an advantage over a labour market approach to 'death rates' as they are more readily interpretable.

\subsection{The National Picture}

The proposition under investigation here is that given the phenomenal growth of the Irish economy in the 1994-2000 period we would expect to find some evidence that business birth rates may be associated with it. In particular, we are interested in identifying evidence that business birth rates were significantly higher in this period either pre-dating or post-dating the 'take-off' in growth. 
The issue of causality is of interest here as we seek to investigate if any rise in business birth rates led to subsequent economic growth.

At the start of $1988^{7}$ there were just over 75,000 VAT-registered businesses in Ireland and by the end of 2004 there were around 220,000 (Table 1). In other words, the stock of businesses had just about tripled in little more than 15 years. Moreover, the growth in the business stock exceeded population growth by a considerable margin: in 1988 there were 22 businesses per thousand population, and by the end of 2004 there were 56 businesses per thousand. This is a remarkable change, made all the more striking because much of the growth was concentrated in a relatively short period 1994-2000 (see Figure 1).

Charts (a), (b) and (c) of Figure 1 record the components of change in the stock of businesses, with the stock itself displayed on panel (d). In chart (a) we have 'gross births': the number of new businesses registered plus the number of older businesses re-registered; in chart (b) 'deaths', the number of businesses whose VAT registration was cancelled; finally, in chart (c) we have 'net births', gross births less deaths, that is, the number of businesses actually added to the register during the year. This last figure is equal, by definition, to the change in the stock of businesses during the year.

Looking across the charts ${ }^{8}$ which for ease of interpretation have the period of rapid economic growth delineated with a vertical line at the years 1994 and 2000, the proximate origins of the growth in the stock can be identified. From chart (a) we can see that up until 1994 the number of new registrations (of course we are including re-registrations too but these are relatively small in number each year) had been almost constant at between 12 and 13 thousand a year. In 1995 it started to move up, levelling off at an annual rate in the mid-20s after the downturn hit at the beginning of the new decade. The death rate (chart (b)) reached a plateau at around 9 thousand in the early 1990's, and remained there, not following births up until almost the end of the decade, then it plateaued again at around 14 thousand - after the year 2000. There was, perhaps surprisingly, no detectable impact of the downturn in 2001 on deaths, rather it seems to have affected the number of business births for 2-3 years. 
The combined effect of these differing time patterns in births and deaths can be traced in chart (c). The net birth number was around 4 thousand annually in the early 1990s. It moved up with births in 1995 as deaths remained unchanged, and then flattened a little towards the end of the decade as deaths moved up. With the resurgence of births after 2001, and deaths remaining on its new plateau $(14,000)$, the number of net births has moved up quite steeply since 2002, and with it, of course, the number of businesses. Clearly then, the 'active ingredient' in this narrative gross births.

However, if we are seeking to understand the evolution of the number of businesses over time it is useful to scale the components of change by the stock (i.e., the ecological approach to standardisation as outlined above): transforming births and deaths into ratios expressed as a percentage of the stock. As we can see from the four charts in Figure 2 the growth rate of the stock shows little trend. The death rate (chart (b)) is essentially flat, ${ }^{9}$ which means the gross and net birth rates (charts (a) and (c)) are parallel (illustrated in chart (d)). More significantly, given the investigation of the link between new venture creation and rapid economic growth in Ireland, the vital rates (gross and net births and deaths) record similar rates of growth at the beginning (1988), the middle (1998) and the end (2004) of the period.

Whilst the stock of businesses in Ireland has grown in number quite remarkably over the period 1988 to 2004, the raw numbers themselves are a little misleading since we can clearly see from Figure 2 that, after standardisation, a continuation of the growth rates experienced in the late 1980s would have produced a similar sized stock of businesses as was actually recorded in 2004. Therefore, there does not appear to be any evidence of a 'Celtic Tiger' effect in business stock growth. By this we mean that the observed dynamic of the population of businesses in Ireland over this period would appear to be operating independently of factors which were driving Ireland's rapid economic growth. Evidently Ireland's economic growth was not driven by a rise in new venture creation, nor can we associate this period of rapid economic growth as providing a stimulus to increased gross or net birth rates. This is an important conclusion for policy-makers as they seek to develop enterprise policies designed to stimulate economic growth through the process of business start-up interventions. $^{10}$ 
Let us return briefly to the issue of FDI. As reported above, FDI has been seen as an important driver of Ireland's rapid growth since 1994 but, notwithstanding the link (Gorg and Strobl [2002], Gorg and Strobl [2003]) between the presence of manufacturing MNCs and a positive effect on business entry in manufacturing since the mid-1980s, our analysis would suggest that this effect has not intensified since the mid-1990s. In other words, with the increase of FDI flows into Ireland in the mid-1990s, there would not appear to have been an increase in the gross or net business birth rate one might expect.

\subsection{New Firm Formation and Irish Employment Growth}

Annual employment data is not available at the sub-national level in Ireland for the 1988-2004 period so we cannot examine the relationship between new business formation and employment growth at the regional level over time following the methodology devised and applied by Michael Fritsch in recent years (see for example, Fritsch and Mueller [2004]). However, as an initial step, we are able to present a simple correlation between annual employment rates and gross VAT registration rates for this period. Between 1988 and 2004 the number of employees in employment in Ireland rose from 1.1 to 1.8 million an increase of 65.3 per cent (Figure 3 - chart (a)). There was a rapid increase in employment in the 1993-2000 period when annual employment growth rates of 5.1 per cent were recorded, this was a dramatic change: in the previous five years the number of employees remained almost static at between 1.1 and 1.2 million. Since 2000 the rate of growth in employment has proceeded at a much slower pace.

In the same period Ireland's population was also increasing rapidly and it is, therefore, important to present this rising trend in employment as a proportion of the population in each year (Figure 3 - chart (b)). Expressed this way the increase in employment in the 1995-2000 period is brought into sharp relief with the employment rates increasing by 10 per cent in this relatively short five year period. As we have already discussed the trend in gross registration rates over the whole period indicates that new business formation rates in the late 1990s were not significantly different from those observed in the late 1980s

which led us to the conclusion that there was no obvious relationship between 
Ireland's dramatic economic growth and the process of new business formation (Figure 3 - Chart (c)).

For the period as a whole, there is no obvious single relationship between annual rates of new business formation and annual employment rates (Figure 3 - Chart (d)). We can see, for example, that falling gross registration rates from 1988 to 1994 were accompanied with a stable employment rate. It is within this period (i.e., 1990-1995) that annual rates of employment growth in Ireland rose from -0.3 per cent to 5.0 per cent (the employment rate was approximately $45 \%$ in each of these years). Throughout this time the rate of gross registrations remained static at around 12 per cent. The implication here is that a significant number of jobs were being created in the Irish economy (c. 120,000) seemingly unrelated to the process of new business formation and more likely the result of large inward investment projects.

Between 1994 and 1998 (the period of economic 'take-off') the gross registration rate rose by a half and the employment rate by 10 percentage points and then while the employment rate continued to rise to 2000 gross registrations were stable. There then followed a two year period (2000-2002) when gross registrations fell and the employment was stable. Finally, gross registrations rose between 2002 and 2004 while the employment rate was almost flat. The path of the relationship between gross registration rates and employment rates is traced out by the 'Z-shaped' line, tracking the association from 1988 through to 2004.

We have given a purely descriptive account of entrepreneurial activity in Ireland over the business cycle. Although the shortness of the available annual time series limits the scope for examining causality, we did investigate the comovement of these two time series and tested, more formally, whether entrepreneurial activity, as proxied here by VAT registrations, is independent, pro-cyclical, or a leading indicator of the cycle. Koellinger and Thurik [2009] have usefully summarised the literature and concluded that there are two main viewpoints. First, the share of entrepreneurs or new firms in the economy have been thought of as a given and, therefore, not subject to cyclical influence. Second, entrepreneurial activity is a response to changing economic fortunes as individuals weigh up the net benefits of entering or remaining in employment 
against those which may be obtained from self-employment or business ownership. There is some evidence, albeit for Northern Ireland, that business formation is procyclical: Harrison and Hart [1983] found that the unemployment rate (lagged one year) was a significant predictor of new business formation.

Given the limited number of observations in the Irish data $(n=17)$ it is not possible to undertake more than a simple test of whether one time series is useful in predicting another. Such a test does not imply true causality in the sense that it does not allow for additional variables representing other processes to be analysed. Nevertheless, a Granger-type test for causality allows us to make some general observations about the nature of the relationship between these two time series. We found that there is no significant Granger-causality between the two series. At a one year lag there is no causality in either direction and at three year lags (which reduces the observations to 14 i.e., 1991-2004) there is no causality from employment rate to gross registrations but causality is observed at the 10 per cent level from gross registrations to employment rate. ${ }^{11}$ This confirms our earlier observation that there was no obvious relationship between Ireland's 'take-off' and the process of new business formation

\subsection{Sub-National Picture: Business Start-ups at County Level}

We now turn to the sub-national picture, the task is to investigate the variations in the trends in vital rates across bailiwicks. ${ }^{12}$ We do this by focusing on the size of the business stock as we have already established that the growth in the business stock at the national level is a function of gross births - the 'active' dynamic of change in the 1988-2004 period. It is helpful to focus on the subnational level for two key reasons. First, although nationally, there may have been no 'Celtic Tiger' effect in terms of business gross and net birth rates, at the sub-national level there may have been a process of catch-up taking place in which growth rates experienced in the Irish economy since the mid 1990s has led to a convergence in the distribution of new business activity across space. We cannot address the causal connection between annual rates of new business formation and employment change because there are no annual employment data at the county level. 
The size of the business stock varies considerably across bailiwicks. For example, in 2004 there were 34,000 businesses in Dublin City (DUCI) but just 1,251 businesses in Leitrim (LEIT). Moreover, the distribution of businesses across bailiwicks was quite concentrated: taken together, Dublin City and Dublin County (DUCO) accounted for almost one third of the total, whilst the top six largest (in order: Dublin City, Dublin, Cork County (COCO), Galway (GALW), Kildare (KILD) and Meath (MEAT)) together accounted for half of the all Ireland total. Of course, part of this variation can be accounted for by variations in the size of bailiwicks. For example, using the population in 2002 (the most recent year for which we have county and city data), we find bailiwicks ranging in size by a factor of around 20: Dublin County (excluding Dublin City) about 500,000 inhabitants to Leitrim 25,000 inhabitants.

The scatter of the log of the number of businesses against the log of population provides some insight into the cross-bailiwick pattern. As we can see from Figure 4 this log/log relationship is linear and has a slope coefficient which is not significantly different from unity (coefficient of 1.02 with a standard error of 0.03 ). In other words the stock has unit elasticity with respect to population: if a bailiwick has a population 10 per cent larger than another, it will have a business stock which is 10 per cent larger too. To take an extreme example, Leitrim (LEIT), the bailiwick at the bottom left hand corner of the figure, has (as noted earlier) the smallest population $(25,800)$ and the smallest business stock $(1,251)$, whilst towards the other end of the scale we have Cork County (COCO), the third largest population $(324,800)$ and the third largest business stock $(16,220)$. Cork County's population is 13 times that of Leitrim, and Cork County's business stock is 13 times larger too.

Of course, were the point estimate of the elasticity exactly unity, and were all the data to lie on the least squares line, then all the business stock to population ratios would be equal, and equal in turn to the exponentiated value of the constant in the regression. In our example, where both bailiwicks lie very close to the line, the number of businesses per thousand inhabitants is 48 for Leitrim, and 50 for Cork County. However, although most of the data points are fairly close to the line there are a couple of points - notably Dublin County and Dublin City in the top right hand corner - which do fall some distance from it. So we can immediately infer that the rate does vary over a (relatively) small 
range. In fact, it runs from 41 per thousand inhabitants in Laois (LAOI) to 59 in Meath (the all-Ireland figure 52 is close to the mid-point) with an isolated outlier at the top end of Dublin City, at 68 (maybe a beneficiary of a 'capital city' effect).

Now we know that there has been a substantial (i.e., greater than two-fold) rise in the stock of businesses per head in the country as a whole since 1988, so it is worth enquiring how uniform that increase has been across the country. Figure 5 has on its vertical axis the 2004 per capita business stock expressed as a ratio to its 1988 value and on the horizontal axis the 1988 value of the per capita stock. The scatter of points is negatively sloped, which means that counties which had the lowest per capita stocks in 1988 recorded the largest increase between 1988 and 2004. In other words, there was some convergence in the distribution of businesses per head of population over the period.

However, on closer inspection the scatter of points can be divided roughly into two groups: the relationship between the 1988 per capita stock and the 2004 to 1988 ratio appears to have two 'arms'. For similar initial per capita business stocks, bailiwicks on the lower 'arm', close to the dashed line (e.g. Laois (LAOI), Roscommon (ROSC), Donegal (DONE)) recorded lower growth than bailiwicks on the upper 'arm' (e.g. Leitrim (LEIT), Longford (LONG)). Figure 6 a county-level map 1 has been coloured according to this classification with the bailiwicks from the upper 'arm' coloured light grey, and those from the lower 'arm' coloured dark grey, and there is a clear spatial pattern. The bailiwicks from the upper arm: that is, those which converged more than average are, for the most part, in an arc around Dublin (but not including Dublin County itself), and along the border with Northern Ireland. Two other bailiwicks in the west of Ireland - Galway (GALW) and Clare (CLAR) - are also on the upper 'arm'. Elsewhere, the rest of the country displayed a lower than average rate of convergence. $^{13}$

From a spatial viewpoint the doubling of the per capita business stock between 1988 and 2004 has been associated with a degree of convergence with initially under-endowed bailiwicks growing more. However, there is a clear Dublin-bias in the process with most of the fastest converging bailiwicks located relatively close to Dublin. An obvious interpretation of this pattern is that there has been 
some spill-over of growth from Dublin, coupled with FDI stimulating business births in the western counties of Clare and Galway (see the earlier discussion of Gorg and Strobl [2002], Gorg and Strobl [2003]). The series of Irish National Spatial Strategies, the latest of which is for the 2002-2020 period, placed increasing emphasis on emerging spatial clusters of economic activity developed around internationally competitive Irish and foreign-owned firms in order to achieve a more "balanced regional development". The evidence presented here would suggest that, using this rather narrow dimension of the stock of businesses, and the process of 'births' and 'deaths' which lie behind it, some progress has been achieved. However, a detailed consideration of the role of industrial policy (e.g. through more favourable subsidies to firms located in certain areas) and the impact of a National Spatial Strategy on encouraging business start-up activity outside Dublin, while important, is beyond the scope of the current paper.

\section{Conclusions}

Since the 1980s a major component of small firm policy throughout the European Union has been the encouragement of start-up activity resting on the presumption that economic growth was, in part, driven by the entrepreneurial process. However, growing research evidence would suggest that this 'causal' connection has not yet been adequately demonstrated. In this context we take the 'unique' Irish case and address a very simple proposition: if there were a connection between entrepreneurial activity and economic growth, we would expect to find evidence of an increase in the gross and net business birth rate in one of Europe's most rapidly growing economies.

What we in fact found at the national level was that the growth rate in new business venture creation in Ireland in the late 1980s, and early 1990s (i.e., prior to the period of rapid economic growth) were broadly similar to those observed in later periods: both the rapid growth phase (1994-2000) and the period 2001-2004. The implication here is that economic growth can occur at the national level without a concomitant rise in business start-up activity. An examination of the relationship between new firm formation (gross births) and the employment rate in this period (including a Granger-type causality test) confirms this interpretation, suggesting a much more complex set of drivers 
involved in job creation in Ireland. This is an important observation in the context of the constant desire by policy-makers to embrace some notion of a 'business birth rate strategy' as part of a wider economic strategy to stimulate economic growth (see Anyadike-Danes et al. [2005] for a fuller critique).

However, at the sub-national level, we do observe that there has been some degree of convergence in the growth rate of new business activity across Irish bailiwicks (essentially, counties). Apparently, the growth of the Irish economy since the mid-1990s has been associated with a degree of spatial' catch-up' in business start-ups rates. We may be observing here the trickle-down effects of national economic growth manifested through the entrepreneurial process in some more remote parts of Ireland outside Dublin, but mostly in those bailiwicks which are closest to the capital. The existence of a National Spatial Strategy may also have played an active role in this convergence. In other words, we are tending towards a conclusion which argues that national economic growth may have been a stimulus to increasing levels of gross business births at the sub-national level, which in turn may generate economic growth at the regional level.

The process of new business venture creation in Ireland obviously requires further investigation, unfortunately, the lack of spatial time series datasets makes impossible a more formal investigation of the links between birth rates and economic growth at the county-level. 


\section{References}

Acs, Z., O’Gorman, C., Pickernell, D., and Terjesen, S. [2007a]. The knowledge spillover theory of entrepreneurship and foreign direct investment. Jena Economic Research papers, no. 59, Jena University, London.

Acs, Z., O'Gorman, C., and Terjesen, S. [2007b]. Could the Irish miracle be repeated in Hungary? Small Business Economics, 28(2-3):123-142.

Andreosso-O'Callaghan, B. and Lenihan, H. [2006]. Is Ireland a role model for SME development in the new EU member states? Journal of European Integration, 28(3):277-303.

Anyadike-Danes, M. and Hart, M. [2006]. The impact of sector, specialisation and space in the UKs business birth and death rates: a challenge for policy? Environment and Planning C: Government and Policy, 24(6):815-826.

Anyadike-Danes, M., Hart, M., and O’Reilly, M. [2004]. Watch that space! The county hierarchy in firm births and deaths in the UK, 1980-;1999. Small Business Econmics, 25(3):273-292.

Ashcroft, B., Love, J., and Malloy, E. [1991]. New firm formation in the British counties, with special reference to Scotland. Regional Studies, 25(5):395-409.

Audretsch, D. and Thurik, R. [2001]. Linking entrepreneurship to growth. OECD Science, Technology and Industry Working Papers, 2001/2, OECD, Paris.

Bailey, D., de Ruyter, A., and Kavanagh, N. [2007]. Lisbon, Sapir and industrial policy: evaluating the Irish experience. International Review of Applied Economics, 21(3):453-467.

Barry, F. [1999]. Understanding Ireland's economic growth., Macmillan Press, Basingstoke. 
Barry, F. [2002]. The Celtic Tiger Era: delayed convergence or regional boom? ESRI Quarterly Economic Commentary, 21 (Summer):84-91.

Barry, F. [2004]. Export-platform foreign direct investment: the Irish experience. European Investment Bank Papers, 9:8-37.

Bartelsmann, E., Haltiwanger, J., and Scarpetta, S. [2004]. Microeconomic evidence of creative destruction in industrial and developing countries. Discussion Paper, TI 2004 - 114/3, Tinbergen Institute, Amsterdam.

Braunerhjelm, P., Faini, R., Norman, V., Ruane, F., and Seabright, P. [2000]. Integration and the regions of Europe: how the right policies can prevent polarisation. Monitoring European Integration 10, Centre for Economic Policy Research, London.

Buckley, R., Leddin, A., and Lenihan, H. [2006]. An assessment of the contribution of MNEs to the Irish Economy. Presentation to I11 Foro De Economia Regional FPRP Economico De La Rioja, Spain, 9-11 May.

Burnham, J. [2003]. The Celtic Tiger. Wilson Quarterly, 27(3):110-111.

Cassidy, M. [2004]. Productivity in Ireland: trends and issues. Central Bank and Financial Services Authority of Ireland Quarterly Bulletin, pages 83-105.

Department of Finance [1958]. First Programme for Economic Expansion. Report, Department of Finance, Government of Ireland, Dublin.

Ferreira, M. and Vanhoudt, P. [2004]. Catching the Celtic Tiger by its tail. European Journal of Education, 39(2):209-234.

Foley, A. and McAleese, D. [1991]. Overseas industry in Ireland. Gill and Macmillan, Dublin.

Fritsch, M. and Mueller, P. [2004]. Effects of new business formation on regional development over time. Regional Studies, 38(8):961-976. 
Gorg, H. and Strobl, E. [2002]. Multinational companies and indigenous development: an empirical analysis. European Economic Review, 46(7):13051322.

Gorg, H. and Strobl, E. [2003]. Multinational companies, technology spillovers and plant survival. Scandanavian Journal of Economics, 105(4):581-595.

Gray, A., editor [1997]. International perspectives on the Irish economy. Indecon Economic Consultants, Dublin.

Gudgin, G. and Hart, M. [1994]. Spatial variations in new firm formation in the Republic of Ireland, 1980-90. Regional Studies, 28(4):363-376.

Gudgin, G., Scott, R., Hanvey, E., and Hart, M. [1995]. The role of small firms in employment growth in Ireland, north and south. In Bradley, J., editor, The two economies of Ireland: public policy, growth and employment. Oak Tree Press, Dublin.

Harris, W. [2005]. Secrets of the Celtic Tiger. Issues in Science and Technology, 21(4):23-27.

Hart, M. and Hanvey, E. [1995a]. New firm formation and the job generation debate: some evidence from the late 1980s. Small Business Economics, 7(2):97108.

Hart, M. and Hanvey, E. [1995b]. The role of small firms in employment growth in Ireland, north and south. In Burke, A., editor, Enterprise and the Irish economy. Oak Tree Press, Dublin.

Harrison, RT and Hart, M [1983] "Factors influencing new-business formation: a case study of Northern Ireland" Environment and Planning A, 15, 1395-1412

Honohan, P. and Walsh, B. [2002]. Catching up with the leaders: the irish hare. Brookings Papers on Economic Activity, 2002(1):1-57. 
Johnson, P and Conway, C. [1997]. How good are the UK VAT registration data at measuring firm births? Small Business Economics, 9(5):403-409.

Koellinger, PD and Thurik, R [2009] Entrepreneurship and the Business Cycle, Tinbergen Institute Discussion Paper, TI 2009-032/3.

Love, J. [1995]. The measurement of entry rates: reconsideration and resolution. Empirica, 22(2):151-157.

McAleese, D. [2000]. The Celtic Tiger: origins and prospects. Policy Options, pages $46-50$.

Plummer, L. and Acs, Z [2005]. Penetrating the knowledge filter in regional economies. The Annals of Regional Science, 39(3):439-456.

Robinson, C., OLeary, B., and Rincon, A. [2006]. Business start-ups, closures and economic churn: a review of the literature. Report, Enterprise Directorate, Department for Business, Enterprise and Regulatory Reform, London.

Sapir, A., Aghion, P., Bertola, G., Hellwwig, M., Pisani-Ferry, J., Rosati, D., Vinals, J., and Wallace, H. [2003]. An agenda for growing Europe - making the EU economic system deliver. Report, European Commission, Brussels.

Slaughter, M. [2003]. Host-country determinants of U.S. foreign direct investment into Europe. In Herrmann, H. and Lipsey, R., editors, Foreign direct investment in the real and financial Sector of industrial economies, pages 7-32. Springer Verlag, Berlin.

Storey, D. [1994]. Understanding the small business sector. Routledge, London.

Strobl, E., Walsh, P., and Barry, F. [1998]. Aggregate job creation, job destruction and job turnover in the Irish manufacturing sector. The Economic and Social Review, 29(1):55-71. 
Thurik, R. and Wennekers, S. [2004]. Entrepreneurship, small business and economic growth. Journal of Small Business and Enterprise Development, 11(1):140-149.

van Stel, A., Carree, M., and Thurik, R. [2005]. The effect of entrepreneurial activity on national economic growth. Small Business Economics, 24(3):311321.

van Stel, A. and Storey, D. [2004]. The link between firm births and employment: is there an upas tree effect? Regional Studies, 38(8):893-909.

Wennekers, S. and Thurik, R. [1999]. Linking entrepreneurship and economic growth. Small Business Economics, 13(1):27-55.

Wennekers, S., van Stel, A., Thurik, R., and Reynolds, P. [1999]. Nascent entrepreneurship and local economic development. Small Business Economics, 24(3):293-309. 
Table 1: VAT Registrations, Flows, Stocks \& Vital Rates 1988 \& 2004

\begin{tabular}{|l|l|l|}
\hline $\begin{array}{l}\text { Cumulated Flows: } \\
\text { 1988 to 2004 }\end{array}$ & Numbers & Rate \% (ratio to 1987) \\
\hline Gross Births & 328,889 & 432.2 \\
\hline Deaths & 184,278 & 242.1 \\
\hline Net Births & 144,611 & 190.0 \\
\hline Stocks & Numbers & \\
\hline end-1987 & 76,103 & \\
\hline end-2004 & 220,714 & \\
\hline Ratio 2004/1987 & 2.9 & \\
\hline
\end{tabular}

Source: Irish Revenue Commissioners 
Figure 1: VAT Registrations,1988-2004, '000s

(a) gross births

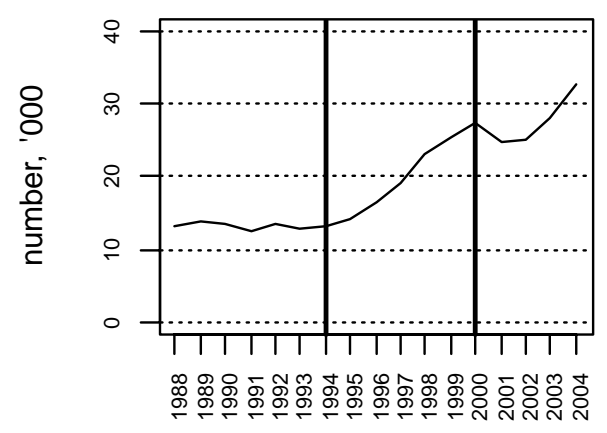

(c) net births

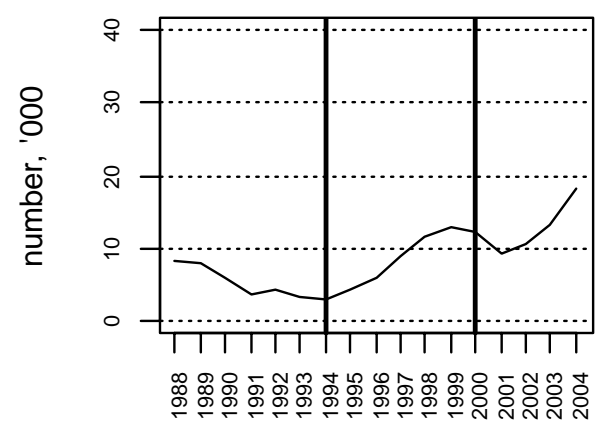

(b) deaths

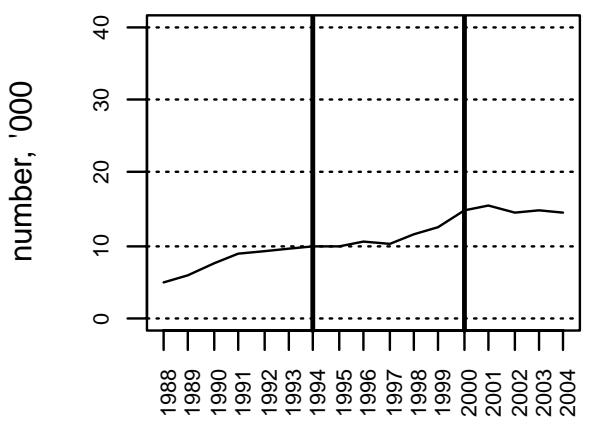

(d) stock

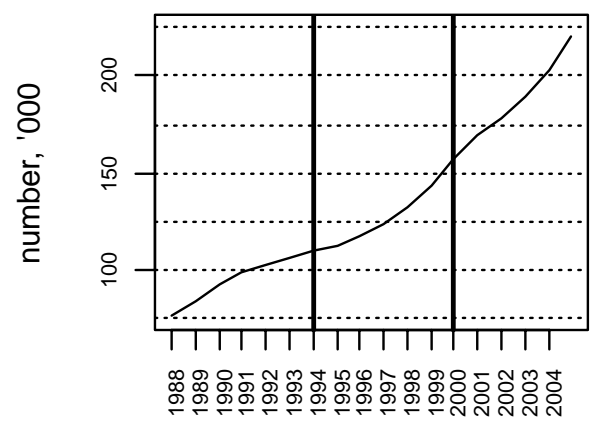


Figure 2: VAT Registrations,1988-2004, ratio to stock \% (a)gross births

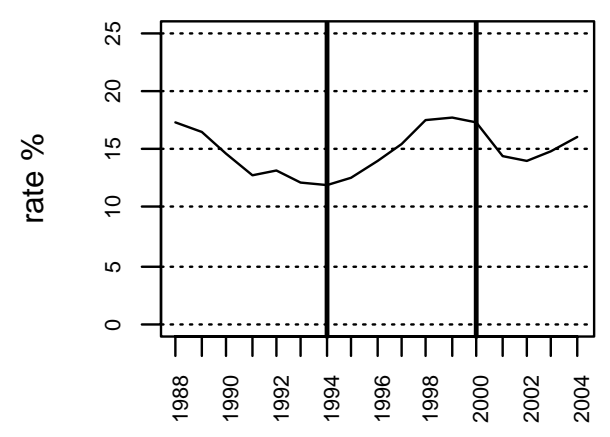

(c)net births

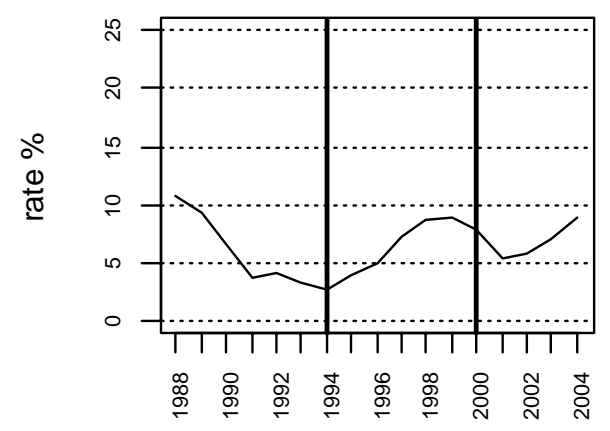

(b)deaths

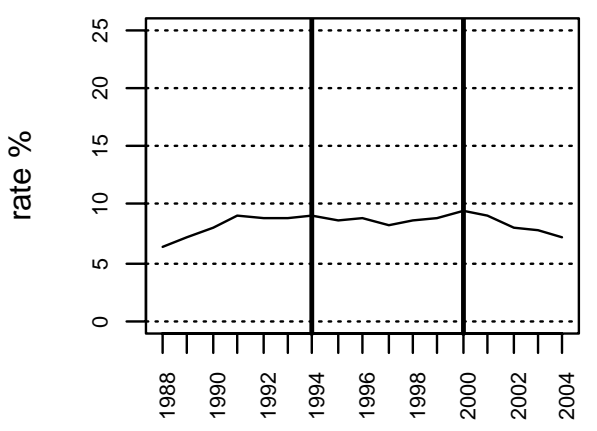

(d)vital rates

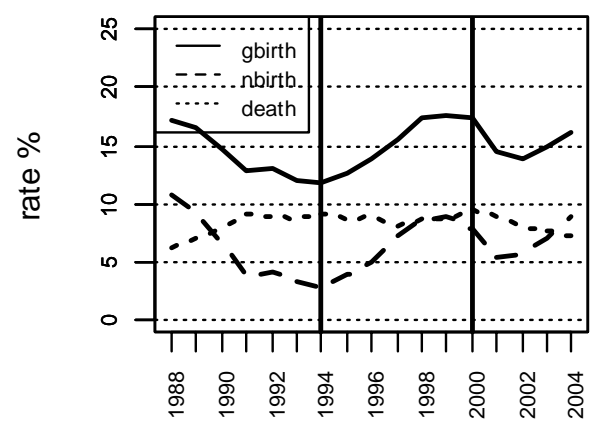


Figure 3: Employment, employment rates \& gross birth rates,1988-2004

(a) employment '000s

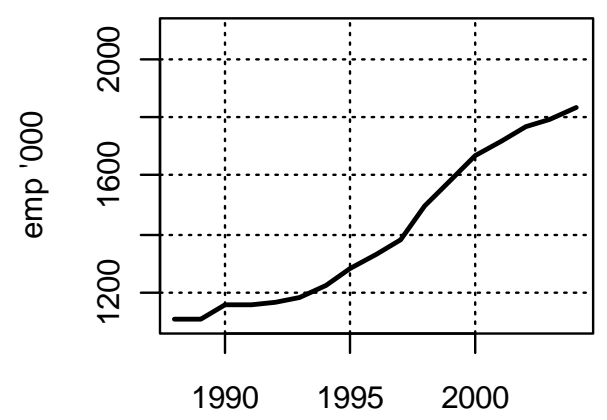

(c) gross reg rate, $\%$

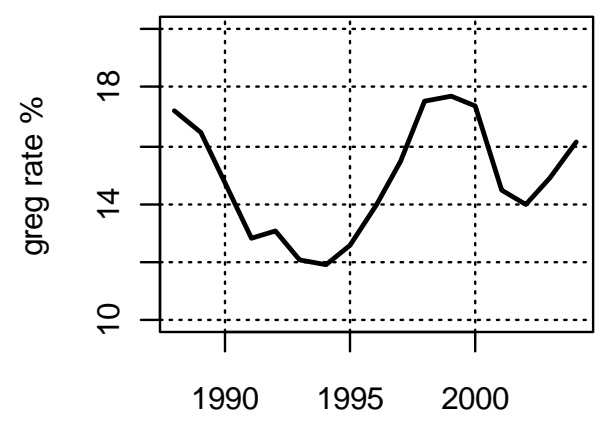

(b) employment rate, \%

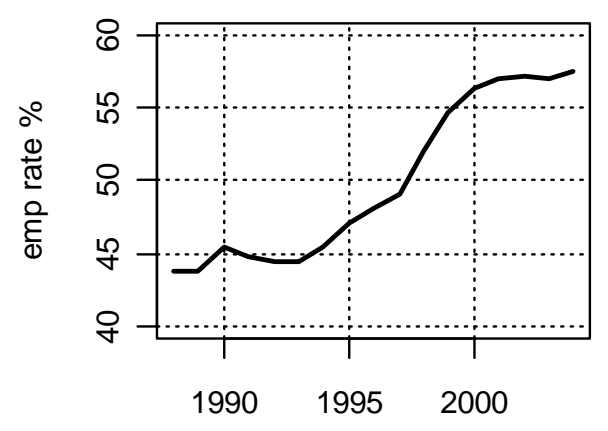

(d) employment rate (\%) vs gross reg rate $(\%$

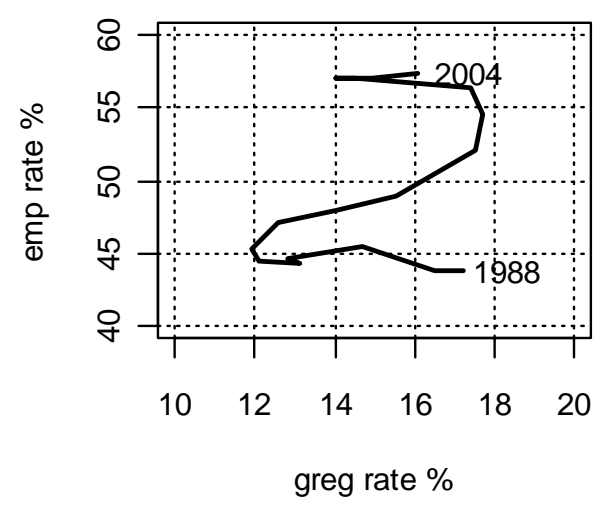


Figure 4: Stock of businesses(2004) vs population (2002) by bailiwick (log vs log)

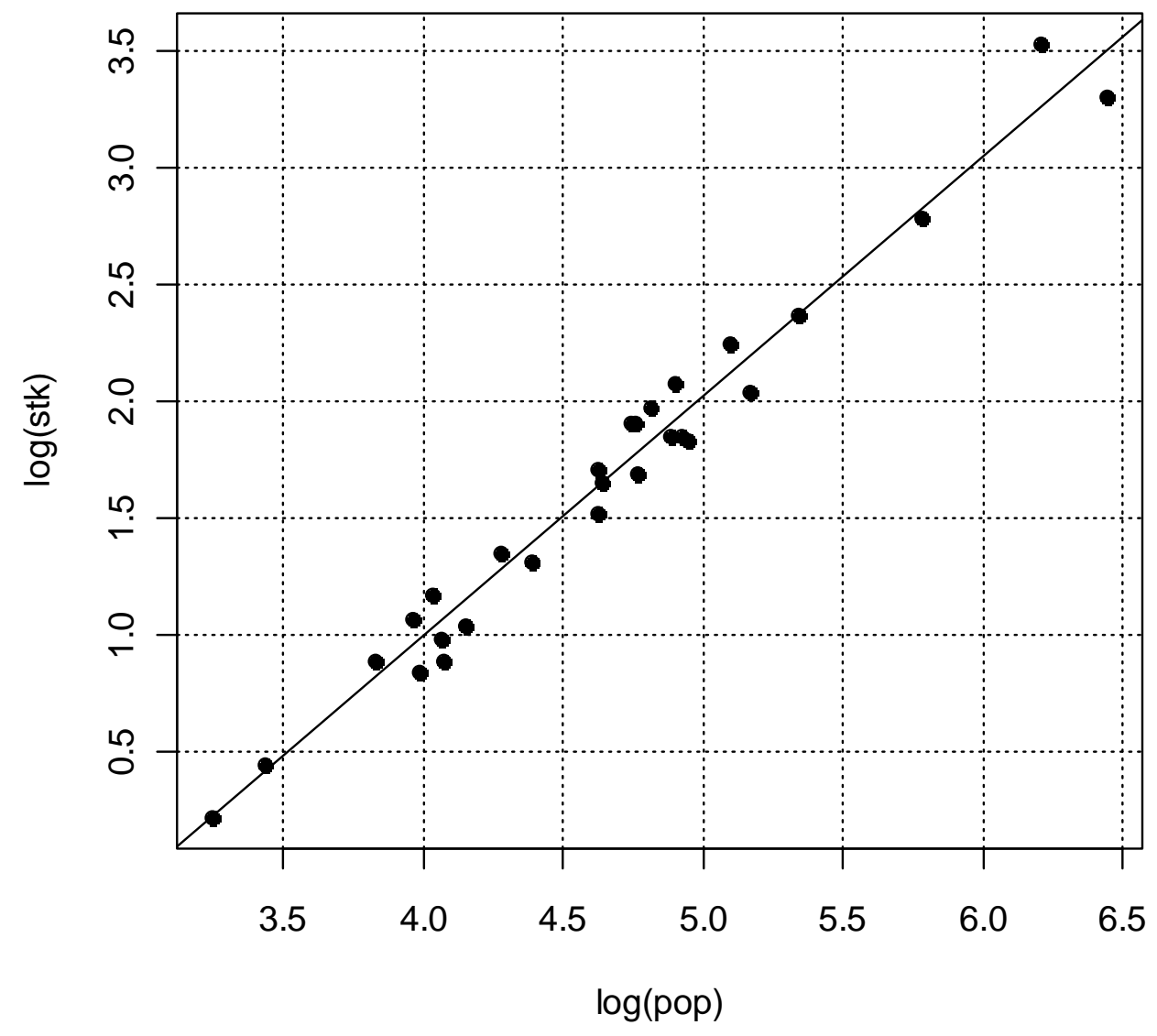


Figure 5: stock of businesses per capita (stkpc), ratio stkpc(2004/1988) vs stkpc(1988),by bailiwick

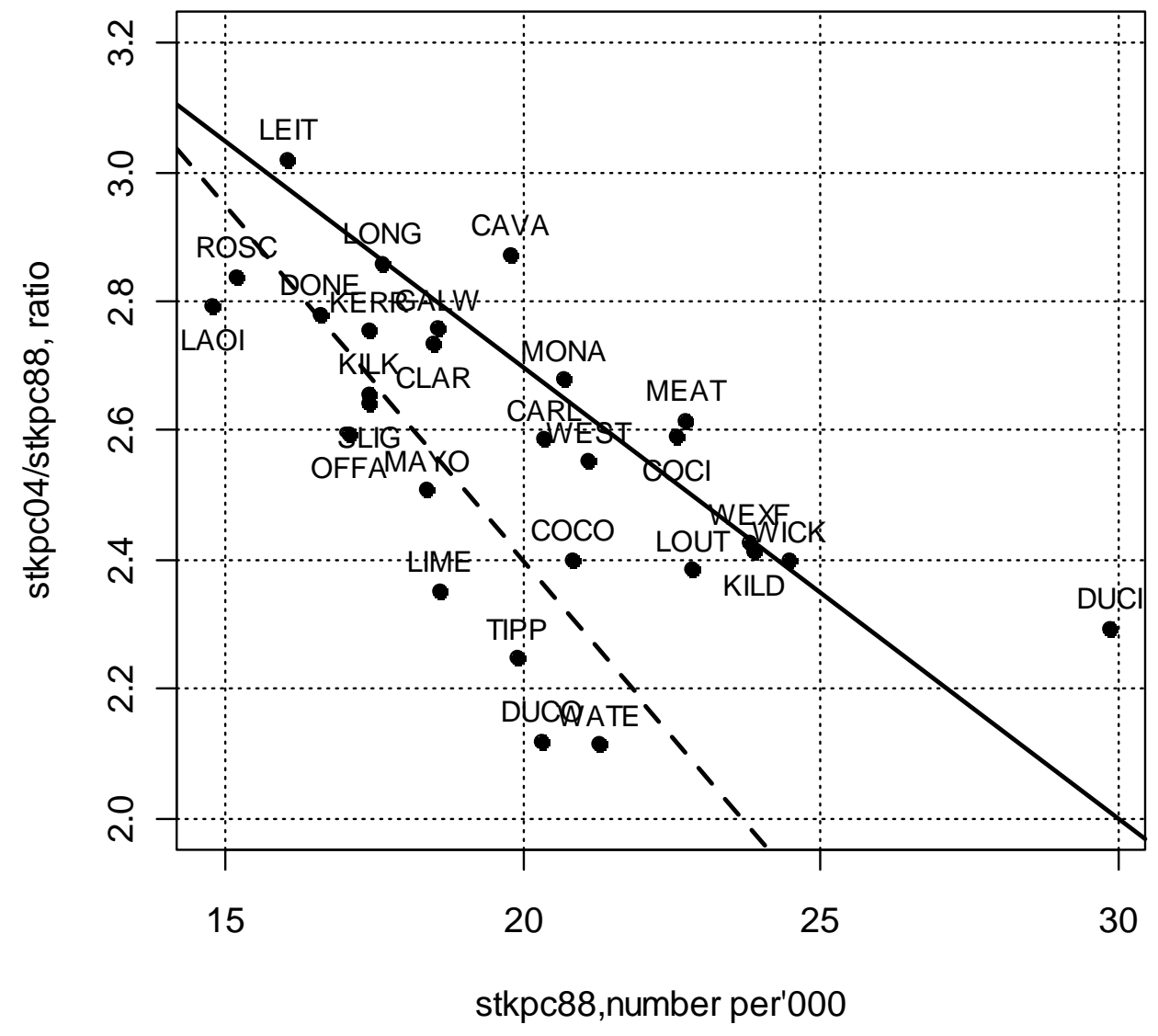




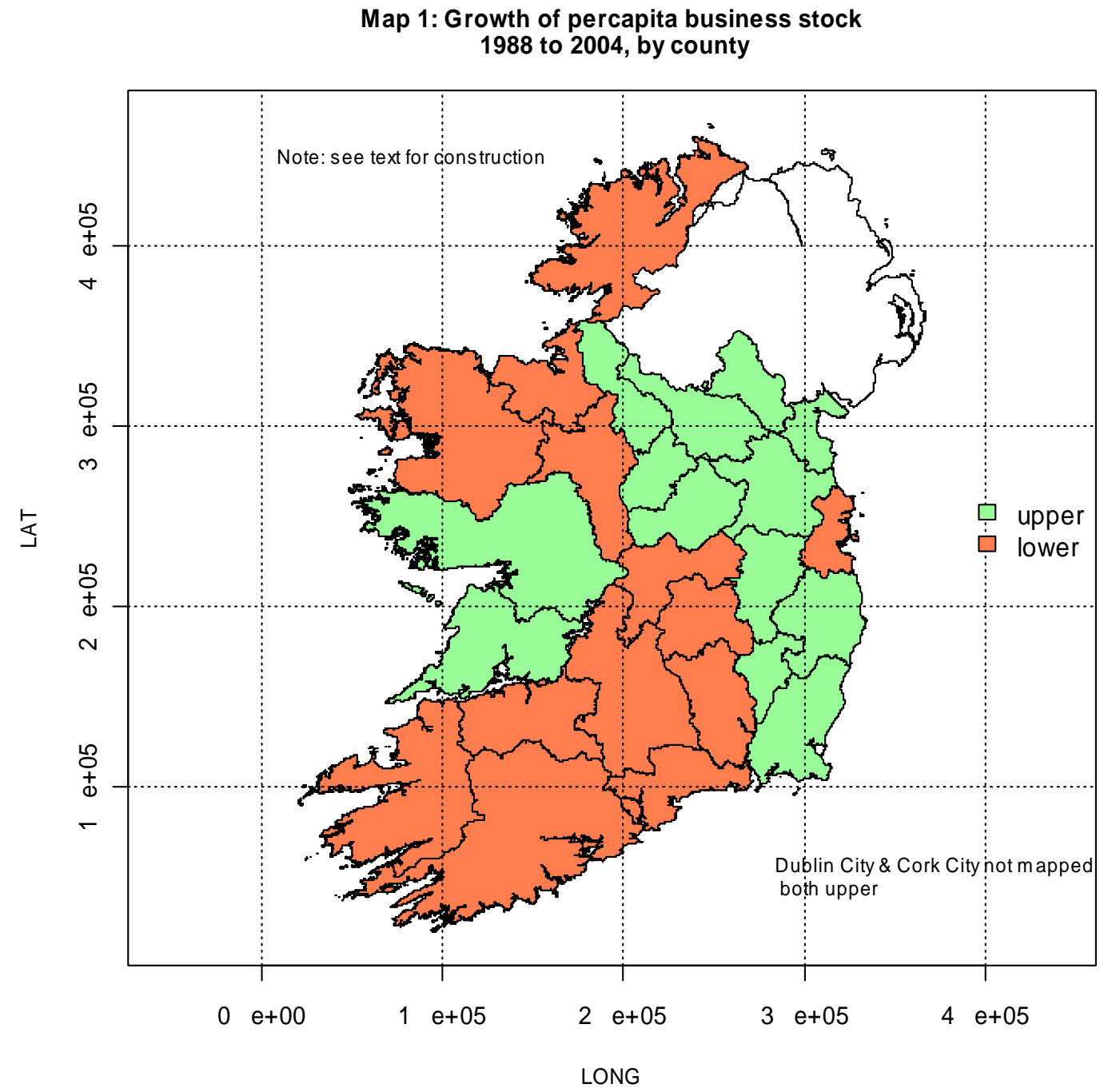




\section{Notes}

${ }^{1}$ For a useful summary of this literature see Robinson et al., [2006]

${ }^{2}$ Previous examinations of the role of new firm formation in national and regional economic growth in Ireland can be found in Gudgin and Hart [1994]; Hart and Hanvey [1995b], Hart and Hanvey [1995a] and Gudgin et al. [1995]. These studies used new firm formation data for the period 1980-90 and 1973-1990 respectively and, as such, are not pertinent to the central research question of this paper. Their overall conclusion was that in the Irish economy it was FDI which was the major component of job generation.

${ }^{3}$ From the aggregate published statistics of the Department of Revenue, Government of Ireland.

${ }^{4}$ The dataset was also classified by four digit NACE code but initial examination of the data suggested that the NACE codes may not always have been applied in the same way. For example, the proportion of registration and deregistrations classified as 'other' was significantly higher in the early years compared to later years.

${ }^{5}$ For example, Johnson and Conway [1997] concluded that VAT data does have the advantage that they are relatively comprehensive, are "official" and are collected on a regular basis. The OECD micro-level dataset on firm demographics uses VAT business registers in many of the industrial countries as a key input into identifying business entry and exit (see Bartelsmann et al. [2004]).

${ }^{6}$ Detailed discussions with officials in the Revenue Commissioners responsible for the Irish VAT statistics confirm that their administrative categories broadly conform to this notion of business 'births'and 'deaths'.

${ }^{7}$ As we observed earlier this was the year the Irish Government announced a tax amnesty. Although it has not yet been possible to estimate how this may have affected the trend of VAT registrations and cancellations in the early years of our study period, it is reasonable to assume that some of the rise in VAT registrations in 1989 and 1990 may be related to this amnesty as businesses not previously registered for VAT took an opportunity to do so as part of a wider legitimisation of their tax affairs.

${ }^{8}$ In each case a single tick mark represents 10 thousand businesses.

${ }^{9}$ Storey [1994, Fig 4.1, p.83] reports a very 'flat' death rate for the UK computed from VAT figures for 1980 to 1991

${ }^{10}$ At an Editor's suggestion we experimented with a different method of constructing the 'net birth rate' data, combining inflows over a period to yield what amounts to a 'moving average' rate, but this made no substantial difference to these conclusions.

${ }^{11}$ Full results available on request.

12 The data is collected for "bailiwicks", these are the administrative unit (or Tax District) historically used by the Revenue Commissioners with (approximately) the boundaries of Irish counties. There are 28 bailiwicks, (roughly speaking) one for each county and one extra each for the cities of Dublin and Cork.

${ }^{13}$ Of course, there is a degree of arbitrariness in this classification, but notice that the bailiwick closest to the upper/lower border Kerry (KERR) is a neighbour to Clare. 
